\title{
As Razões da Escola Médica: Sobre Professores e Seus Valores. Os Valores dos Médicos e os Impasses da Escola Médica
}

\author{
LUCIA GRANDO BULCÃO \\ JANE DUTRA SAYD
}

\section{RESUMO}

Este trabalho teve por objetivo conhecer o professor médico, no que diz respeito a seus valores e comportamentos profissionais, a partir da hipótese de que os mesmos são elementos presentes no chamado currículo oculto ao longo do curso médico. Pressupõe-se, sobretudo, que tais elementos apresentam estreita relação com a formação médica, compondo, ao final, uma cultura adquirida na escola, ao longo do processo de socialização do estudante. Este processo é tão importante para a identidade profissional, para sua pertinência à corporação, quanto a aquisição de habilidades e conteúdos cognitivos relativos ao exercício técnico da profissão. Com este objetivo, o trabalho analisou a história de vida profissional de alguns docentes em uma escola pública do Rio de Janeiro, privilegiando as categorias de autonomia, ideal de serviço, mentalidade clínica e relacionamento interpares da Sociologia das Profissões, além de apreender os relatos específicos sobre a trajetória do médico que se torna professor. Optou-se pela história oral obtida de entrevistas com docentes de diferentes especialidades, em um total de onze entrevistas. Concluiu-se que os professores estão nostálgicos de um passado em que sua profissão apresentava uma situação de prestígio inquestionável e um tanto perplexos frente às novas situações, principalmente de restrições à autonomia liberal. Sem um projeto político para a escola e para a corporação, estão menos motivados do que no passado, e isto pode se constituir como fator negativo na socialização e na formação de valores éticos entre seus alunos.

Palavras-chave: Profissão médica; ensino médico; currículo oculto; história oral. 


\section{Introdução}

Os professores nas escolas médicas são, em sua maioria, médicos. Um aspecto a concorrer, possivelmente, para dificuldades na reforma do ensino médico é a perpetuação dos valores característicos da própria profissão médica, através do ensino e prática docentes. A profissão médica apresenta especificidades relativas a valores e auto-imagem do médico, os quais, ao final, estariam influenciando diretamente os caminhos percorridos pela escola médica, como parte importante do currículo oculto.

Os valores do professor médico são parte da formação do estudante. Os estudantes aprendem não apenas através de modelos - observação e assimilação do exemplo ou padrões - mas também através de seu envolvimento no ambiente da escola, entendida como organização social, num processo de socialização (Rego, 1995). A escola médica seria o contexto institucional no qual se inicia a socialização, através de transmissão de conhecimentos, hábitos, atitudes e valores. Esse processo de socialização tende a reproduzir de forma conservadora os padrões culturais vigentes, os internos à própria estrutura da escola e os valores do mundo profissional, estes trazidos, mesmo que não exclusivamente, pelos professores. Não se poderia esperar que fosse fácil transformar ou apenas reformar pautas de conduta e os valores vigentes em uma Faculdade de Medicina; eles estão associados a pautas e valores de uma das profissões de maior prestígio em nossa sociedade. É necessário levar em conta estes fatores, ao se pensar uma proposta de reforma no ensino médico realista e exeqüível.

\section{Objetivos}

Este trabalho visa a analisar mais profundamente algumas contradições do ensino médico, a partir de uma avaliação de sua relação com o pensamento e valores dos médicos relativos à sua profissão, na convicção de que tais valores são parte importante da formação do estudante. Chaves (apud Almeida, 1999, p. xiii) aponta que, ao se considerarem propostas de mudanças no setor saúde em geral e educação médica, em particular, para além do enfoque centrado nos avanços científico-tecnológicos, "o modelo atual deve sofrer uma metamorfose refletida principalmente na esfera dos valores".

A história oral de docentes médicos de uma escola pública do Rio de 
Janeiro constituiu a fonte para o entendimento dos valores e ideologias desses profissionais e de como estes entendem sua inserção no contexto institucional e profissional ao longo de suas carreiras. Para melhor atender aos propósitos, as entrevistas foram distribuídas entre docentes de diversas especialidades, de forma a contemplar as várias características associadas à mentalidade clínica. Esta pode se manifestar diferentemente entre os médicos, conforme sua prática, seja assistencial (prestação de consultas; lidar com clientela) ou de cunho apenas acadêmico (Freidson, 1970). As entrevistas, doze ao todo, foram abertas, colhidas segundo a técnica de história oral, gravadas e transcritas (Thompson, 1992). Os professores discorreram sobre sua trajetória profissional, desde a motivação para a escolha da profissão e sua formação, até sua trajetória docente na faculdade. As especialidades eram clínica médica, cardiologia, nefrologia, cirurgia geral, cirurgia vascular, otorrinolaringologia, medicina do trabalho, microbiologia (disciplina básica) e saúde pública.

Com base em Freidson (1970), cuja obra aborda características da profissão e a mentalidade clínica dos médicos, elaborou-se uma relação de categorias representativas de valores profissionais, sobretudo autonomia e ideal de serviço. Analisaram-se também as informações sobre a origem e trajetória profissional dos docentes, seus pontos de vista sobre o hospital universitário, sua própria atividade pedagógica e a inserção social de sua profissão.

A maioria dos professores entrevistados manifestou elevado sentimento altruísta em relação à melhoria de condições de vida da sociedade. Muitos declararam envolvimento com movimentos de oposição (partidária ou não) ao governo arbitrário vigente em sua época de estudantes, almejando perspectivas de melhoria do desenvolvimento social, revelando forte militância na política e no movimento estudantil.

"A história da faculdade é uma história de luta. Luta para melhorar a faculdade, o ensino, luta durante a ditadura, onde vários alunos foram presos e torturados. A luta para conseguir esse hospital e para que ele melhorasse" (nefrologista, formado em 1963).

\section{Origem Social e Motivação para Escolha da Carreira}

Os docentes entrevistados são, em sua maioria, oriundos de classe média, com pais funcionários públicos, professores, profissionais liberais e comerci- 
antes. Apenas um professor declarou ascendência humilde: “(...) meu pai era operário, é (...) pobre!". Dois docentes declararam serem filhos de pais médicos, e cerca da metade tem pelo menos um parente próximo médico, conforme pesquisas sobre a origem dos médicos (Machado et al., 1995). A ligação familiar é geralmente relatada como uma influência na escolha profissional, o que também corrobora outros estudos (Schraiber, 1993) que mostram comportamentos de médicos no sentido de uma continuidade do trabalho e posição familiares:

“(...) a escolha de uma profissão depende muito do convívio familiar (...) o meu avô era médico, dois tios médicos, pai médico. (...) eu sempre convivendo com médico, ambiente médico, relacionamento médico (...)” (cirurgia vascular, 1960).

“(...) se meu pai não fosse médico, se eu não tivesse tido essa influência familiar (...) quando era pequeno eu ia ao hospital em que meu pai trabalhava, eu olhava, né (...) então foi mais ou menos um caminhar normal (...)" (clínica médica, 1960).

Muitos se referiram ao rigor dos exames vestibulares de sua época para as faculdades de Medicina. Apesar das dificuldades de acesso e no decorrer do curso, verificam-se baixos índices de abandono. Essa tradicional adesão ao projeto profissional é explicada pelas dificuldades encontradas para se cursar Medicina. O esforço pessoal para superar os inúmeros obstáculos da formação médica faz com que o indivíduo valorize mais a carreira, o que reduz os índices de abandono.

“(...) Alguns estavam já no quinto, sexto ano, quase médicos, eles tinham medo de perder uma posição que lutaram muito e duramente para atingir. Ele ia ser médico" (ciências básicas, microbiologia, 1976).

\section{As Especialidades e os Valores Profissionais}

A "mentalidade clínica", os valores e comportamentos do médico variam conforme a prática exercida (Freidson, 1970). Assim, por exemplo, os valores relacionados ao ideal de serviço e a preferência em trabalhar com pessoas são mais evidentes entre os médicos que prestam consultas, enquanto que o pragmatismo e a preferência pela atividade que solucione problemas são característicos de cirurgiões; interesses econômicos em de- 
trimento do ideal de serviço aparecem mais comumente entre os especialistas, quando comparados aos clínicos gerais.

Utilizando a classificação de Machado et al. (1995), a maior parte dos entrevistados está nas especialidades cognitivas (cardiologia, clínica geral, medicina do trabalho); dois docentes trabalham em especialidades técnicocirúrgicas e dois pertencem à classificação das especialidades intermediárias (otorrinolaringologia e nefrologia); dois docentes têm especialidades tecnológicas e/ou burocráticas (um pesquisador em microbiologia e um sanitarista). Os cirurgiões entrevistados valorizam mais aspectos relativos a técnica e habilidades, bem como afinidade com solução de problemas:

"Eu gosto de resolver os problemas (...) O sujeito do coração morre do coração. A não ser que opere com um cirurgião. Por isso fui fazer cirurgia (...). A cirurgia resolve muitos casos (...) não cura todo mundo. Mas cura muita gente (...)" (cirurgia geral, 1959).

“(...) Depois, a cirurgia endoscópica tira a maior arma do cirurgião, que é a palpação. Então você vai operar uma vesícula, apalpa o intestino e vê o tumor do de cólon. E você trata na mesma hora. Com a endoscopia você não vê" (idem).

Quanto aos atributos necessários ao cirurgião:

"Tem que gostar de consertar as coisas. Tem que ter habilidade manual. Não precisa ser muito hábil. Mas o sujeito que é (...). Eu acho que todo cirurgião tem que começar na cirurgia geral. Porque o que dá finesse, dá delicadeza, é tripa, é intestino. O intestino, se você apertar ele (...), quando você soltar, ele faz uma fístula. O coração é um músculo, que você pode apertar que não tem problema (...) O cirurgião geral trabalha com os órgãos delicados" (cirurgia geral, 1959).

$\mathrm{O}$ depoimento que denota mais preocupação quanto à presença de elementos de racionalidade psicológica, na relação do médico com o paciente é de um docente formado numa especialidade cognitiva. Verifica-se, também, o grande enfoque no indivíduo, característico da profissão médica em geral $^{3}$.

“(...) o médico tem uma amplidão, uma visão maior, o médico mexe com a coisa mais difícil que existe, que é o indivíduo, não é? (...) medicina é fácil, na medida em que você trata do doente do pescoço pra baixo. Quando se insere a cabeça, a medicina se torna extremamente difícil. (...) A medicina é 
uma profissão diferente porque mexe com o indivíduo. Com a intimidade dele" (clínica médica, 1960).

Identificamos, ainda entre clínicos, pontos de vista condizentes com a caracterização das especialidades cognitivas, privilegiando o raciocínio clínico no ato médico:

"Antes, eu achava que medicina era algo do diabo. Depois eu verifiquei que não, que isso tinha uma lógica de raciocínio (...) E até hoje eu continuo fazendo o mesmo exercício diagnóstico" (nefrologia, 1963).

O médico docente-pesquisador de área básica, por outro lado, de acordo com as referidas características de seu tipo de especialidade (tecnológica/ burocrática), demonstrou uma vocação oposta ao enfoque individualassistencial. Além disso, referiu-se à medicina apenas como um meio para atingir o mundo da ciência.

“(...) [o cuidado] não era essa (...) a minha motivação (...) talvez porque eu identificasse na medicina a possibilidade de eu ter acesso ao mundo da ciência. (...) a possibilidade de investigar a causa, por exemplo, do por que as pessoas adoecem, de que maneira isso acontece (...) Nunca me atraiu ser um cirurgião (...) nunca!” (microbiologia, 1976).

Identificamos igualmente, no discurso do médico sanitarista, elementos que denotam uma preocupação fora do centro indivíduo-assistência, privilegiando o coletivo. Seu enfoque se caracteriza por uma visão social e política:

“(...) Gostei do velho. Já se falava dele como o cara que enxergava a necessidade de se debater as questões da medicina social, enquanto os reacionários de plantão achavam que isso era coisa de comunista" (sanitarista, 1969).

\subsection{O tornar-se docente (e a questão da preparação didático-pedagó- gica): o valor da experiência pessoal}

Os professores apontaram a carreira docente como acidental, de início. Todos fizeram parte de uma geração em que não se exigia concurso para ingressar no magistério público. Assim, a grande maioria relata o "tornar-se professor" como indicação e convite de algum tutor ou catedrático da universidade. 
As Razões da Escola Médica: sobre Professores e seus Valores. Os Valores...

“(...) fui convidado a ficar como médico no hospital. Aí, fui chamado para ser professor simultaneamente (...)” (clínica médica, 1968).

“(...) Eu não era professor coisa nenhuma. Eu era um médico que estava se especializando. A escolha dos professores era feita de acordo com as pendências que a pessoa mostrava (...)" (cirurgia vascular, 1960).

"Bem, médico torna-se professor acidentalmente (...) e então eu fui nomeado médico do serviço (...) E um belo dia me passaram a professor; não era concurso, e sim indicação" (clínica médica, 1963).

O "tornar-se professor" é percebido por alguns docentes como uma passagem natural - de médico do hospital universitário a docente, como se fosse inevitável que a assistência médica num hospital universitário estivesse, já de antemão, vinculada ao ensino.

“O médico tinha que dar aula também (...)” (clínica médica, 1968).

“(...) Porque eu não fui preparado, isso é uma coisa que aconteceu naturalmente comigo" (clínica médica, 1960).

Revelam, assim, que não houve nesse processo uma preparação prévia, específica, para a carreira docente. O "ser docente" e o ensino ficam à mercê de qualidades e tendências de cada professor. A experiência individual passa a ser considerada suficiente, pré-requisito para o exercício docente.

“(...) São qualidades pessoais, eu acho que é o desenvolvimento das qualidades individuais de cada um. (...) a minha forma de ensinar eu adquiri com a minha experiência ensinando" (clínica médica, 1960).

Essa afirmativa vem ao encontro de um tradicional valor da profissão médica: a experiência pessoal. A experiência adquirida pelo médico é de suma importância para esse profissional, podendo justificar sua conduta sem levar em conta, inclusive, orientações acadêmicas e científicas.

\section{O Prestígio Profissional e as Dicotomias: generalista, especialista, prática hospitalar e ambulatorial}

Houve referências à profissão médica como facilitadora de mobilidade do indivíduo, que "abre portas", no sentido de uma ascensão social: "A medicina ainda era um grande passaporte, na época, para se chegar a qualquer lugar 
que você quisesse". A perda do prestígio social da profissão, percebida pelos médicos ao longo dos anos, constitui ponto de conflito e desgaste para esses profissionais. Identificam-se inúmeras expressões de lamentação e indignação em face da progressiva deterioração da imagem do médico, se comparada ao grande prestígio social desfrutado no passado. A perda de prestígio social da profissão médica é associada ao grande número de escolas médicas e formandos, o que desvalorizaria o profissional em termos de mercado. O perfil atual do médico, em termos de origem social e cultural, não sustentaria o antigo prestígio usufruído pela medicina, profissão ligada, no Brasil, à elite social:

“(...) o médico involuiu, perdeu prestígio, deixou de ser o sacerdote que era tido na época do meu avô (...) primeiro porque havia poucos médicos, hoje em dia há excesso de médicos. Segundo, porque ele tinha de ser um profissional de conduta ilibada para ser respeitado" (cirurgia vascular, 1961).

De forma semelhante, observamos depoimentos que lamentam a desvalorização e perda de prestígio em relação à docência. Tal percepção se dá, muitas vezes, por referência a um passado no qual esse profissional era mais valorizado socialmente.

"Naquela época, ia o professor na frente, todo paramentado, com aquela bata longa, o primeiro assistente, o segundo assistente, os alunos (...)" (cirurgia vascular, 1961).

"Hoje, já não é mais assim. Não só pelo lado financeiro (o professor ganha muito mal) como também pelo lado da atualização, carreira que já não tem mais tanto valor" (clínica médica, 1968).

Através dos depoimentos, observamos a associação do prestígio social às diferentes formas de trabalho médico. O prestígio varia entre as diferentes especialidades e entre a prática geral e especializada. Evidencia-se menor valorização da clínica médica, o que suscita depoimentos que chegam a ser um desabafo dos docentes da área.

"Na época, os grandes líderes da medicina eram os clínicos (...) e ela deve ser [a elite] ela não é mais não sei o porquê (...)" (clínica médica, 1960).

"O clínico geral, para as pessoas de classe média, é visto como profissional de baixa categoria. O pobre, não, ele quer um médico" (clínica médica, 1968). 
Da mesma forma que os clínicos gerais, os cirurgiões se ressentem da perda de prestígio de sua especialidade:

“Acho que hoje o cirurgião está tão por baixo (...) já foi o tempo em que eram os príncipes da medicina. Mas não são mais (...)” (cirurgia geral, 1959).

No discurso dos docentes em geral há consenso no sentido de que o objetivo geral e o conteúdo curricular da escola médica devam ser a formação de clínicos gerais, voltados para as áreas básicas. As especializações deveriam, assim, ser escolhidas na residência ou após a graduação. Para alguns, a indefinição de tais propósitos por parte das escolas daria margem à opção precoce, já durante a graduação, de especialidades.

“(...) Eu acho que a faculdade tinha que se dedicar à pediatria, à obstetrícia, clínica médica (...). Esse currículo precisa ser revisto (...) e a gente precisa saber o que é que a nossa faculdade quer. Eu acho que a nossa obrigação é formar generalista. A especialização é depois. É a residência" (cirurgia geral, 1959).

"O nosso currículo não está voltado para nada. É uma porcaria. O aluno acaba optando logo por uma especialização (...)” (clínica médica, 1968).

“(...) E a formação básica do médico deve ser a clínica médica; então a clínica médica tem que ter um conteúdo maior na formação do médico (...)” (clínica médica, 1971).

Critica-se o progressivo processo de especialização do ponto de vista da relação do médico com seu paciente. Esta se daria de forma ideal quando houvesse confiança - considerada essencial - entre as partes, o que não ocorreria na medicina especializada. Na visão dos docentes, o ideal de relação médico/paciente vem-se perdendo ao longo do tempo, na medida em que a especialização aumenta.

“(...) todo esse caminho errado que a medicina passou, da superespecialização, o cara é um superespecialista, não existe vínculo entre o doente e o médico (...) no que acabou isso (...) acabou a medicina. A medicina se baseia em uma coisa chamada relação médico/paciente. No momento em que isso não existir, acabou! (...)" (otorrinolaringologia, 1961).

A confiança aparece como elemento de grande importância, até mais valorizado para a qualificação do médico do que sua competência técnica. 
"Esse negócio de muita especialidade, eu acho um absurdo. Tem que ter o médico generalista, como tem que ter o médico de família, a quem a família recorria. Tinha confiança (...). É importantíssimo. Tanto que o melhor médico não é o mais bem preparado. É o que o doente tem mais confiança (...)" (cirurgia geral, 1959).

Atributos como cultura e competência médicas são referidos como componentes necessários ao clínico geral. Percebe-se, quando se evocam atributos formadores de uma auto-imagem favorável, um movimento de resgate da valorização desse profissional: "Você, para ser clínico, precisa ter espírito, precisa ter competência, precisa ter cultura médica, né?". Paradoxalmente, no entanto, os próprios professores alegam que os responsáveis pelas disciplinas gerais têm menos prestígio na faculdade. O professor do terceiro ano, por abordar disciplinas relativas à clínica médica não especializada, semiologia ou propedêutica, exibe menor prestígio na instituição de ensino. Ressentimento e mágoa são a tônica das falas desses profissionais em relação ao assunto:

"Porque na realidade você é professor do terceiro ano, é a coisa mais importante da clínica. (...) você tem que dar importância a todos os indivíduos de uma faculdade de medicina, a todos eles" (clínica médica, 1960).

“(...) Existe uma certa divisão entre o professor que dá aula para o terceiro ano, que a princípio parece que não está tão atualizado quanto os outros (...) Não é porque você vai ensinar propedêutica médica (...) que você não vai falar do último método diagnóstico" (clínica médica, 1971).

O próprio currículo tende a destinar menos horas para o ensino de clínica médica:

“(...) mas o curso era muito bom, não só pela qualidade como pelo tempo que hoje a gente não tem mais. (...) era o terceiro ano inteiro, hoje a gente está lutando ferozmente para que continue o ano todo porque querem cortar, querem que sejam seis meses; clínica médica, que é no quarto ano, no meu tempo era o ano inteiro" (cardiologia, 1968).

A especialização como alternativa de mercado de trabalho não é, no entanto, contestada: espera-se que a faculdade, mesmo formando generalistas, tenha especialistas após a residência, por problemas de mercado de trabalho:

"Na verdade existe uma coisa chamada mercado, que é uma causa que clama 
As Razões da Escola Médica: sobre Professores e seus Valores. Os Valores...

por especialista. Agora é que começamos a ter programa de médico de família com salários melhores. E a gente pode dizer que esses médicos de família são oriundos dessa visão generalista (...). E essa questão é meio esquizofrênica. O maior empregador público é o INAMPS, e todos os concursos são para especialistas. E mesmo agora, não sei se é verdade, mas não houve nenhum concurso para médico de família sem ser institucionalizado" (nefrologia, 1963).

O professor aponta a esquizofrenia na lógica da organização da atenção à saúde. Considera que a melhor relação médico/paciente e a melhor cultura médica estão no clínico geral - ou seja, no limite, em nossa sociedade a boa medicina não é possível. A superespecialização seria uma prática distorcida e menos desejável, porém a única realmente prestigiada socialmente.

\subsection{A excelência do hospital, a precariedade do ambulatório}

O local de trabalho do médico - unidade hospitalar ou extra-hospitalar é outro elemento que atribui maior ou menor prestígio ao profissional. $\mathrm{O}$ hospital é o local de trabalho mais prestigioso, onde são tratadas as patologias de maior complexidade A utilização de instituições hospitalares para o aprendizado mostrou-se de suma importância para os docentes entrevistados, estando intimamente ligada a uma boa formação e à qualidade da escola médica. As referências ao período de aquisição do hospital-escola para a universidade mostram sua importância. Para alguns, a ausência de um hospital-escola motivou uma reivindicação organizada nesse sentido.

“(...) veio o grande choque de saber que não existia o hospital-escola, (...) eu estava numa faculdade muito ruim. Todas as faculdades enxergam a necessidade do hospital-escola, sem o qual o curso médico não poderia alcançar melhor qualificação" (clínica médica, 1963).

A efetivação do funcionamento do hospital-escola também fez parte da luta dos estudantes e professores por melhorias no âmbito do ensino médico. Esse processo se alinha à concepção de que o hospital constitui o local ideal de aprendizado. O hospital recém-adquirido foi um estímulo tão importante, na época, que suplantava inclusive uma remuneração precária:

"Olha, ganhava-se miseravelmente mal. Eu ganhava muito mais no [Hospital dos] Servidores do que aqui (...). Mas eu não sei se é o entusiasmo, porque ganhamos um hospital, todo mundo veio trabalhar (...)" (cirurgia geral, 1959). 
“(...) tirando São Paulo, essa era a única Faculdade de Medicina que tinha hospital. Isso na época representava coisa de outro mundo (...) então isso pesava, assim, absurdamente, na escolha da faculdade" (cardiologia, 1968).

Nesta escola específica, a aquisição do hospital-escola foi o grande motivador para a melhoria da qualidade do ensino e do empenho coletivo em trabalhar para uma instituição de excelência, nos anos 70 .

"Éramos um grande hospital, com uma faculdadezinha nos fundos. O hospital encobria as dificuldades da faculdade. Na medida em que o hospital foi caindo, ficaram à mostra nossas dificuldades (...)" (clínica médica, 1968).

A importância do hospital na identidade da faculdade fica bem evidente na observação do clínico. Ao se referir às falhas na formação do estudante, cita o ambiente hospitalar, não a figura jurídica da faculdade: "O hospital se esqueceu de formar o generalista!” (clínica médica, 1968).

A identificação do médico com o ambiente hospitalar típico de enfermaria é tamanha que praticamente inviabiliza as reformas que propõem ensino mais centrado na prática ambulatorial. É a contradição entre a prática docente e os objetivos propostos para a formação:

“(...) inclusive o atual diretor da faculdade diz que há vários paradoxos. Um deles é que, apesar de haver consenso de que o ensino deve ser ambulatorial, não tem um professor que tenha se mandado para o ambulatório (...)" (clínica médica, 1963).

Os relatos, realmente, mostram a pouca consideração atribuída ao ambulatório para as atividades de ensino:

“(...) os três primeiros anos, o aluno não tem que entrar no hospital (...) cadeiras básicas. Depois, quatro anos, começa a vir para o hospital. E fica dentro do hospital (...)" (cirurgia geral, 1959).

“(...) Como aluno, a gente fazia ambulatório, mas não tinha muito ambulatório no terceiro ano e no quarto anos. Era mais um trabalho de enfermaria mesmo (...)" (clínica médica, 1971).

Há relatos em que os próprios docentes expressam simplesmente que não gostam do trabalho em ambulatórios, preferindo atuar em enfermarias hospitalares:

"Ele funciona mal. (...) o RX, hoje. Só se vê o resultado daqui a um mês. 
No ambulatório não se faz esta ligação com o paciente. (...) No internato, o ambulatório é uma obrigação chata" (clínica médica, 1968).

Um dos entrevistados, ao relatar seu empenho para reverter tal processo, evidencia a relutância dos professores da escola médica em realizar suas atividades de ensino no espaço ambulatorial:

“(...) Nós levamos os estudantes do currículo clínico, do quarto ano, para o ambulatório. E quem orientava esses estudantes era o residente, porque não havia professores lá, ou então médico do hospital" (clínica médica, 1963).

O professor, francamente a favor da especialização, minoritário em seu discurso, é taxativo: o atendimento ambulatorial não é trabalho de mérito num sistema de saúde hierarquizado:

“(...) E escalonado de acordo com a capacidade e responsabilidade: um hospital central, para casos complicados, mais evoluído, e daí vai descendo até o ambulatoriozinho lá da favela, e de acordo com a patologia esse paciente seria orientado para uma maior capacitação médica" (cirurgia vascular, 1961).

O mesmo professor resume o elemento-chave para o prestígio profissional em moldes tradicionais: a gravidade da doença com que lida. A avaliação dessa gravidade ou importância é reduzida, de modo simplista e inverídico tecnicamente, aos fatores ambiente de trabalho (hospitalar ou ambulatorial) e formação (especializada ou generalista).

"Tem que ter o especialista. Quanto mais você se especializa, melhor você fica naquele setor (...) O generalista (...) eles querem botar o médico meiasola, que cada vez mais vai fossilizar e ficar tratando de parasita intestinal" (cirurgia vascular, 1961).

\subsection{Orientação para o serviço}

Esse atributo, que se caracteriza por servir aos interesses da coletividade, é tradicionalmente associado com a profissão médica, embora Freidson (1970, p. 178) argumente que o mesmo "não parece ser um valor muito proeminente comparado a outros" ${ }^{4}$. Para o autor, não há evidências de que, atualmente, a orientação para serviço ou coletividade esteja fortemente presente entre os profissionais.

Embora em nosso estudo tenhamos encontrado alguma referência ao ideal de serviço nos termos expostos ("Nossa geração era empurrada para 
ter uma mentalidade social (...)"; “(...) não vê no aluno aquilo que você via antigamente (...) Ninguém pensa no social, ninguém pensa no coletivo"), a maior parte dos depoimentos se identificou com a afirmação de Freidson, de que a orientação para serviço ou coletividade se manifesta mais por "ajudar indivíduos" do que por servir à sociedade e à Humanidade. Sabe-se que a orientação para a coletividade, embora presente no profissional médico em geral, pode aparecer em diferentes intensidades, conforme a especialidade médica escolhida, de forma ambivalente quanto ao desejo de ganhos econômicos (Freidson, 1970). Neste estudo, o desejo de ser útil aos outros ficou claro nos depoimentos, revelando forte ideal de serviço dos docentes. Tal orientação para serviço ou coletividade, já prevista entre as práticas que têm envolvimento com clientela, manifestou-se da mesma forma entre clínicos e cirurgiões.

"Aí eu cresci ouvindo falar de um médico que tratou da minha mãe (...) os parentes elogiavam pela grande dedicação Então ficou esse homem como símbolo de algo que eu desejava ser (...), o modelo passado para mim foi de um sujeito com grande senso humanitário" (nefrologia, 1963).

“(...) até hoje, eu chego aqui, tem quatro, cinco doentes me esperando. Eu atendo de graça. Eu tenho prazer em atender (...)" (cirurgia geral, 1959).

“(...) nós temos que ter amor àquilo que nós estamos fazendo e aos indivíduos. Porque quem é inimigo do indivíduo não pode ser médico" (clínica médica, 1960).

$\mathrm{Na}$ visão dos docentes, a maneira de o médico se relacionar com o paciente está diretamente associada ao ideal de serviço. O desejo de ajudar expressa-se, assim, na forma da relação médico/paciente. O médico "amigo, conselheiro, que escuta" - expressões constantemente utilizadas para representar o desejo de ser útil aos outros.

"Você tem que estar junto do seu doente, conversar com ele, para que ele identifique em você algo mais do que um sujeito que vai dar uma receita (...) é muito importante a relação médico/paciente" (nefrologia, 1963). 
As Razões da Escola Médica: sobre Professores e seus Valores. Os Valores...

\subsection{Valores relacionados ao trabalho: autonomia profissional}

\subsubsection{A escola médica sem autonomia técnica e pedagógica}

A idéia de autonomia profissional é fundamental para o professor médico - o fator que permitiria condições de exercício profissional adequadas. $\mathrm{O}$ valor de autonomia é grande tanto no âmbito profissional quanto no docente, e quase todos os problemas identificados pelos entrevistados se referem à perda de autonomia nas decisões sobre o ensino. A escola médica sem autonomia técnica e sem autonomia pedagógica apresentou-se como fator importante de desgaste profissional para o educador médico.

Alguns relatos revelam apreensão quanto a um processo de perda de poder de decisão por parte de médicos e professores, identificado, por exemplo, na dificuldade em se dividir o espaço do hospital com outros aprendizados que não o médico:

"Há uma tensão contínua no hospital de clínicas, principalmente entre a enfermagem e os médicos. Os médicos se sentem cada vez mais ameaçados (...). Temo que haja transferência de responsabilidades, que seriam essencialmente médicas, para um profissional que não está preparado necessariamente para assumir essa responsabilidade. Há áreas específicas das quais os médicos não podem abrir mão" (microbiologia, 1976).

Identifica-se um "mal-estar" entre os médicos diante do uso, também por outros profissionais de saúde, do hospital universitário para formação profissional, ocorrência considerada prejudicial à formação médica específica. Os professores consideram o próprio corpo docente como a espinha dorsal do hospital e, portanto, elemento decisivo na qualidade de ensino.

“(...) mas a via final dessa hierarquia é o médico, porque sem ele o hospital não funciona. Não adianta encher isso aqui de enfermeiro, fisioterapeuta $\mathrm{e}$ nutricionista, que não resolve o problema (...)" (clínica médica, 1960).

"A aula de anatomia era dada por um cirurgião (...) que sempre fazia referência à sua prática. O professor que não é médico [do curso básico] não dá uma boa sofisticação. Nesse caso, não há a riqueza da experiência pessoal para a formação do médico" (clínica médica, 1968).

Há dificuldades em se aceitar o compartilhamento do currículo com professores não-médicos de áreas básicas, o que acarreta uma piora no relacionamento (já tenso) entre os profissionais dos dois segmentos. Identificam- 
se conflitos no enfraquecimento do poder decisório dos médicos sobre as disciplinas do currículo, em processos que não se desenvolvem de forma integrada e harmônica entre a faculdade, institutos e hospital:

"A entrada do Instituto de Biologia no básico da faculdade foi deletéria. Acentuou uma distância que nunca devia ter existido (...) quando o hospital foi elevado à condição de unidade de ensino, foi uma retirada de poder de decisão pedagógica e, daí para a frente, os chefes de clínica devem vassalagem ao diretor do hospital, e não da faculdade, pois é lá que está o dinheiro" (sanitarista, 1969).

"A faculdade se enfraqueceu com a criação dos institutos. A faculdade praticamente começa no terceiro ano, por causa dos institutos (...) deveria ter uma estrutura pedagógica que pudesse definir papel e limitação dos institutos (...). As ciências básicas são necessárias para o desenvolvimento da carreira médica e também da área de pesquisa, mas o sujeito não deve ficar preso ao currículo básico, como é hoje (...)” (clínica médica, 1968).

O pensamento dominante é de que a formação de um profissional clínico - fator desejável - estaria prejudicada, com perda da qualidade de ensino, pela lógica da pesquisa nos institutos básicos e a perda de controle pelos médicos, do ensino no hospital, à medida que este também abriga, hoje, alunos e práticas didáticas de outros trabalhadores em saúde.

\subsection{A desmotivação}

Vimos que o "tornar-se docente", para os médicos entrevistados, não decorreu de uma vocação, aspiração ou planejamento de vida profissional. Assim sendo, é compreensível que surjam conflitos em relação à sua atuação como docentes. A natureza do trabalho docente implica atividades outras, diversas da profissão médica puramente assistencial. As atividades de docência não são eminentemente marcadas pelo pragmatismo e particularismo próprios da profissão médica. E também não satisfazem o desejo de ajudar os outros - ligado ao ideal de serviço, atributo importante da profissão médica. A ausência de elementos constitutivos da profissão médica propriamente dita pode suscitar sentimentos de frustração para o médico, que tem sua auto-imagem e realização pessoal calcadas na figura do profissional médico.

Identificou-se, no discurso dos professores médicos, grande desmotivação 
com as atividades de ensino. Os professores manifestam descontentamento com as condições de exercício docente na faculdade. Nos depoimentos, deixam evidente que ser professor não tem trazido satisfação e realização profissional.

“(...) e o ensino do estudante mudou. Mudou na medida em que não temos a motivação dos professores para dar aula para estudantes de graduação. E o compromisso de dar aula para os estudantes é muito chato. No passado, este era o compromisso da instituição. Era o ensino da graduação" (microbiologia, 1976).

No seguinte relato são evidentes, além dos sentimentos já referidos, o desgaste e desestímulo dos docentes quando devem se dedicar somente a atividades de ensino.

“(...) se você passa o ano inteiro como docente, tudo bem, você tem suas alegrias porque você vê que forma os alunos (...). Mas no momento em que você fica ligado mais a isso, deixa de ver as outras coisas (...). Então fica difícil, a gente se ressente, alguns professores se ressentem, que falam disso, não sei se a maioria (...)" (clínica médica, 1971).

Provavelmente, o despreparo dos docentes em relação a uma formação pedagógica contribui para o sentimento de desmotivação e desgaste emocional em relação ao ensino:

"O currículo é fundamental, sem ele não se começa. Mas não é sozinho, necessita-se de postura pedagógica, consciência de que são professores. Ser professor não é uma mera decorrência de ser um bom médico" (clínica médica, 1968).

Um dos depoimentos, ao analisar o perfil dos docentes atuais (considerados alienados e preocupados em demasia com projetos pessoais) relata mesmo "ojeriza" em relação ao ensino:

"A turma que está entrando por concurso ultimamente, de uns quatro ou cinco anos para cá, são todos brilhantes, são ótimos, passam brilhantemente no concurso, todos já têm mestrado, só que a cabeça deles já é completamente diferente da nossa, eles não vestem mais a camisa da faculdade como a gente vestia. (...). E têm ojeriza ao ensino. Quando a nossa geração sair, eu queria assistir de cadeirinha, como é que vai ser para programar um curso de terceiro, quarto ano, de propedêutica (...)" (cardiologia, 1968). 
No discurso do professor pesquisador entrevistado, percebe-se uma insatisfação na "quase obrigação" em ter que se dedicar a atividades de ensino, que, por sua vez, o "desviariam" das atividades de pesquisa. Para ele, o desenvolvimento destas - que "num país como o nosso" já são bastante adversas e demandam bastante dedicação - é dificultado pelo tempo que se deve aplicar ao ensino médico e não à pesquisa.

"Mas realmente é cansativo, né? Porque a atividade de pesquisa, especialmente para um país como o nosso, é muito desgastante. E, além disso, você tem que dedicar boa parte da sua carga horária ao ensino? Corrigir provas dos estudantes, ministrar aulas para um público freqüentemente desmotivado (...). Então você tem que (...) se direcionar para aquele público (...) eu tenho que falar sobre infecção hospitalar, mas ao mesmo tempo tenho que atender o público que não tem noção do que é o DNA. Como é que eu vou compatibilizar isso? É duro, é um esforço muito grande, e muito desgastante" (microbiologia, 1976).

O sentimento de desestímulo em relação ao ensino, tendo como ponto de partida o corpo discente, é compartilhado por vários docentes. Além do baixo nível de conhecimentos considerados pré-requisitos para a formação médica dos alunos ao entrar na faculdade, o nível de cultura e de conhecimentos gerais também é bastante criticado pelos professores.

"Principalmente a parte docente do terceiro ano, que é uma parte desgastante, cansativa porque o aluno vem, não só com deficiências técnicas, mas com deficiências de formação de uma maneira geral, até de língua portuguesa" (clínica médica, 1971).

"De uns dez anos para cá, o nível de conhecimento geral do aluno (...) pra mim, piorou (...) que o povo não lê, mas os alunos também não lêem (...). E eu acho que o nível cultural humanístico caiu 50\%" (clínica médica, 1960).

Ainda em relação ao corpo discente, parece que a visão dos professores sobre os alunos atuais em relação aos de sua época, no tocante à participação na vida institucional, contribui para o sentimento generalizado de desmotivação do profissional no interior da escola médica.

“(...) a efervescência cultural da época, muito bom (...) o aluno da época era mais participante do que o de hoje. Quanto a isso não há mais dúvida nenhuma" (clínica médica, 1968). 
As Razões da Escola Médica: sobre Professores e seus Valores. Os Valores..

“(...) é a política, a política de interesse. De interesse acima da política ideológica. (...) O estudante hoje não participa em nada, o estudante é morto! Morto, morto, morto, na universidade é morto" (otorrinolaringologia, 1966).

A faixa etária do estudante ao chegar à faculdade também constitui ponto de conflito na visão do professor, em relação ao potencial de aproveitamento do aluno. Da imaturidade dos estudantes, segundo eles, decorre uma postura pouco consciente frente às responsabilidades da carreira médica e do curso de medicina.

“(...) Medicina é uma carreira, assim, muito transcendental. Eles não têm noção. Aí, quando eles caem na realidade (...)” (clínica médica, 1960).

“(...) eles são mais jovens, entram na universidade bem mais jovens. E eu acho uma parte deles extremamente infantil (...)” (microbiologia, 1976).

\subsection{A escola médica e a educação continuada de seus docentes: o valor profissional da necessidade de estímulo intelectual}

Sabe-se que o desejo de estímulo intelectual é importante atributo para o médico, o qual, de forma geral, faz investimentos dessa natureza em seu trabalho (Freidson, 1970). A maioria dos docentes entrevistados se ressente com a falta de oportunidades de reciclagem de sua formação profissional e manifesta necessidade de uma educação continuada.

"Em todas as especialidades médicas isso acontece. Não estou falando só do hospital, estou falando em tudo. Falta de fornecimento de meios para a modernização e desenvolvimento técnico do profissional (...)" (cirurgia vascular, 1961).

Além disso, os profissionais se queixam de que a iniciativa para esse tipo de atividade tem ocorrido individualmente, e não promovida pela instituição.

“(...) As coordenações deveriam ter todo o interesse de dar esse salto qualitativo para seus coordenados (...). Isto é, dar outra chance, aquilo que eu chamo de recapacitação (...). Mas a recapacitação não é só você fazer um curso de mestrado ou de doutorado, ela tem que ser contínua, a aprendizagem é contínua (...)" (clínica médica, 1972). 


\subsection{Crise: hospital universitário}

O sentimento de desmotivação dos docentes em relação à faculdade também deve ser relacionado à insuficiência de recursos investidos na instituição. Os professores, em sua maioria, vivenciaram períodos de maior afluxo de verbas e melhor funcionamento do hospital, e condições materiais de atendimento à população. Assim, comparam momentos diferentes de condições de trabalho, o que faz aumentar o sentimento de desmotivação atual, em relação a um período percebido como mais bem-sucedido.

“(...) Hoje, o hospital está na falência. (...) A cirurgia (...) o corpo clínico deste hospital é muito bom. O que está faltando é apoio. Esse hospital tinha que ter uma ressonância! Esse hospital tinha que ter uma radioterapia!" (cirurgia geral, 1959).

“(...) E hoje eu fico triste, (...) nós não tínhamos nada. E ele cresceu, cresceu, cresceu, depois ele cresceu pouquinho, horizontalizou mais, não houve um progredir natural que a gente esperaria” (clínica médica, 1960).

Alguns docentes comparam diferentes momentos em relação a referenciais humanos, cuja perda contribuiria para deteriorar a instituição de ensino:

"Essa época que eu falo que foi a época de ouro, nós tínhamos alguns elementos referenciais (...). Na verdade essa questão é de substituir quadros (...). E na verdade, a partir dessa época de ouro, a história da faculdade é uma história de perdas (...)” (nefrologia, 1963).

Em relação ao ensino propriamente dito, os docentes manifestam preocupação com a qualidade da formação médica, ameaçada em decorrência da precariedade de recursos materiais e tecnológicos. Avanços tecnológicos e equipamentos de ponta estariam diretamente ligados ao maior estímulo ao ensino; desses elementos dependeria, ainda, uma adequada formação de recursos humanos. O hospital, carente desses recursos, contribuiria para a deterioração do ensino e uma formação médica precária. "Aqui houve uma grande queda do hospital (...) e como o hospital piorou, o ensino também caiu". Percebe-se que os docentes se sentem ameaçados com a falta de investimento e de atualização tecnológica em relação tanto à qualidade do trabalho desempenhado, quanto à sua auto-imagem e estima, de profissional qualificado. 
As Razões da Escola Médica: sobre Professores e seus Valores. Os Valores...

“A formação médica está confusa (...) pela deficiência de recursos. Essa parte confusa, eu entro também na capacitação. Você não pode ensinar num aparelho que você não tem. Então você começa a formar, hoje, médicos de ontem" (cirurgia vascular, 1961).

“(...) lâmina? Sem bacteriologia, como é que eu vou trabalhar?” (clínica médica, 1960).

"A medicina piorou (...) A partir de 74, começam a surgir novas tecnologias e nós não tínhamos capacidade para adquirir essa tecnologia. E o pior é que nós deixamos sucatear todas as tecnologias que nós tínhamos (...)" (nefrologia, 1963).

A deficiência de recursos financeiros foi diretamente relacionada, pelos professores, à deterioração do ensino:

"A defíciência se manifesta em todas as faculdades. (...) É em função das dificuldades de aparelhos, dificuldades de verbas. No fundo, no fundo, você vai, roda e volta à falta de verbas. A crise é geral, está em tudo" (cirurgia vascular, 1961).

“(...) então nós começamos a ter salários aviltados ${ }^{5}$, enfim, o hospital começou a ter várias dificuldades para se manter, cada vez mais cortes. Agora mesmo cortaram. O município cortou um milhão de faturamento do hospital por mês, isso é um negócio calamitoso" (cardiologia, 1968).

Observamos que, intensificando o sentimento de desmotivação, manifesta-se um sentimento de impotência em relação ao desejo de modificar e melhorar as condições de exercício profissional na instituição:

“(...) isso pode vir em sentido contrário? Tipo, vamos nos organizar melhor, melhorar a cultura geral com conceitos filosóficos, humanísticos (...) Mas eu, com 36 anos de vida aqui dentro, não posso acreditar muito e há dez, vinte, vinte e cinco anos atrás eu comecei a querer melhorar, e comecei a ver que não consigo, a gente não consegue" (clínica médica, 1960).

Ao final, observamos que as perspectivas e expectativas dos professores, em termos de condições de trabalho e realização profissional, não são exatamente otimistas:

"Hoje em dia a minha geração está muito mal. É, muito amargurada. Tanto que estamos todos nós pensando com muita insistência até em aposentado- 
ria. (...) o que eu acho que aconteceu (...) são coisas que independem da faculdade (...)" (cardiologia, 1968).

"O Hospital dos Servidores era o melhor da América do Sul. Hoje, não é nada! O Hospital da Lagoa era excepcional. O Hospital de Ipanema era um dos maiores, de cirurgia. Estão acabando com a medicina, e com o ensino é a mesma coisa!" (cirurgia geral, 1959).

“(...) É pena que eu estou vendo que no final da minha carreira aqui dentro, o hospital, eu queria que ele tivesse melhorado mais. Eu queria que ele tivesse crescido mais" (clínica médica, 1960).

\section{Considerações Finais}

Os professores entrevistados compuseram um relato multifacetado, contraditório, em que são revelados aspectos conservadores muito próprios das características da profissão médica, tal como já relatava Freidson, em 1970. Simultaneamente, a técnica de colher informações por meio de relatos de suas trajetórias profissionais nos dá uma visão evolutiva das mudanças por que vem passando o exercício profissional, se não no Brasil, ao menos no Rio de Janeiro. O tom nostálgico relativo a uma era de ouro da faculdade coincide, na verdade, com o tom nostálgico de outros profissionais em outras situações, como descrito por Schraiber (1993), em São Paulo.

A escola médica, sem autonomia técnica e sem autonomia pedagógica tornou-se importante ponto de conflito. Os docentes se sentem sem autonomia para conformar seu currículo, "ameaçados" pela estrutura do hospital universitário, este responsável pelo faturamento, através da prestação de serviços. Por outro lado, o Instituto de Biologia da universidade tem realizado seus "ideais de pesquisa", além de conseguir impor o currículo de cadeiras básicas aos estudantes de medicina.

Vimos que, também para nossos professores, a ausência de formação pedagógica constitui ponto de conflito - a tal ponto que a associamos (tendo em vista as declarações a respeito) com a desmotivação docente com o ensino médico. Pensa-se que o preparo prévio para a docência contribuiria para facilitar a relação do professor com o ensino em geral. A maior parte encara o ensino como uma decorrência (e que "têm" que fazer) da assistência médica que prestam no hospital. Como referido por eles, foi uma passagem "natural". Não foram preparados e, como constatado, nem se 
propunham, inicialmente, a exercer atividades de ensino. A docência, enfim, não fazia parte do projeto de vida dos professores - para eles, a docência havia "cruzado seu caminho", sem planejamentos pessoais.

Bastante relevante (e preocupante) para uma reflexão da escola médica é o ressentimento generalizado nos clínicos em relação aos colegas e à sociedade em geral, tendo em vista a forma como vêem ser tratada sua especialidade. Sentem-se desvalorizados e desprestigiados, mesmo entre os colegas de outras especialidades. Essa visão talvez se encontre estreitamente ligada à ascensão e prestígio social atribuídos às especializações, as quais, por sua vez, são as mais procuradas pelos futuros médicos. Vemos entre os docentes de clínica médica manifestações de ressentimento e alusões a um "esquecimento" de si como profissionais de uma especialidade. Segundo documentos de escolas e associações, consolidados pela OPS e FEPAFEM:

\begin{abstract}
"A superação da contradição entre formação de especialistas e médicos gerais exige que a educação médica enfrente criticamente a determinação tecnológica do critério médico de qualidade, que envolve tanto a ética profissional como a eqüidade (...). É necessário continuar a formar melhores especialistas e, ao mesmo tempo, é necessário resgatar e fortalecer a formação geral na graduação, colocando-os adequadamente nas equipes de saúde, promovendo igualmente suas funções e reconhecimento sociais" (Almeida, 1999, p. 63).
\end{abstract}

Nessa linha se constata uma contradição entre o discurso médico, que afirma a importância de formar clínicos gerais e ao mesmo tempo atribui menor valor a esse tipo de formação em relação à especializada, inclusive com a formação clínica resistindo a se voltar para a formação geral. Do mesmo modo, as propostas que visam ao deslocamento do eixo hospital/ atenção individual/especialização acabam suscitando conflitos e oposições à sua efetivação. Propostas centradas em ambiente ambulatorial ou unidades extra-hospitalares que contemplem práticas generalistas trazem dúvidas e insegurança para o profissional. Sem dúvida, tais considerações estão na base da contradição entre a atenção médica que se quer prestar e a ausência de recursos humanos (os quais não se "formam") para viabilização da proposta.

Neste contexto, e contribuindo para a resistência às reformas, um ponto a se destacar é a dificuldade dos professores em se adaptar à prática de atendimento primário em unidades extra-hospitalares. O trabalho em assistência primária ou ambulatorial é encarado com intolerância e insatisfação. Sentimentos de desvalorização, por parte do médico, quanto a esse tipo de 
prática, acabam sendo desencadeados, e a dificuldade do professor em lidar com esse tipo de clientela tenderá a se reproduzir no aluno.

Em geral, os professores se ressentem da ausência de uma política de investimento na educação continuada de sua formação profissional. Nos relatos, a reciclagem profissional, o engajamento em pesquisas, incentivos à atualização tecnológica foram citadas pelos docentes. Tais elementos tornam-se mais importantes quando compreendemos sua importância como representantes de um estímulo intelectual - atributo relevante para o médico e sua profissão (Freidson, 1970). Supomos que, mesmo sem intenção prévia, ao concordarem em trabalhar como professores universitários, estes já pretenderiam atender, em parte, sua necessidade de estímulo intelectual. Pelo visto, porém, trabalhar em uma universidade por si só não basta. Os professores médicos necessitam, para uma realização profissional plena, estar constantemente atualizados quanto aos avanços técnico-científicos da profissão. Também não se sentem autônomos e capazes de prover por si próprios essa atualização.

O eixo que compõe o ideário do docente médico é formado por pontos de vista relacionados a elementos da profissão médica, sendo o ensino considerado pelos entrevistados uma decorrência ou parte do exercício profissional. No entanto, essa correspondência se dá mais na "transferência" de valores do indivíduo como profissional médico para a educação médica do que na concepção da docência médica como expressão única de atividades de ensino e atividades de assistência a doentes. As críticas aos alunos proferidas pelos professores demonstram que o corpo discente constitui fator de desgaste e desmotivação para os profissionais. Em relação aos alunos, os depoimentos evidenciam que o nível de conhecimentos específicos da área, o nível de cultura geral - considerados precários - e a imaturidade decorrente da faixa etária precoce com que chegam à faculdade são fatores negativos, capazes de interferir no aprendizado.

$\mathrm{O}$ valor da confiança entre o médico e paciente foi elemento preponderante, destacado nos depoimentos da maioria. Em seus pontos de vista, essa relação de confiança está atrelada à forma de trabalho médico - especializado ou prática geral. Tal elemento, assim, dificilmente apareceria na forma de trabalho especializado, onde a relação médico/paciente se dá, conforme o pensamento dominante, de modo tecnicista, impessoal, sem afetividade, visando a interesses econômicos - "desumanizada". O atendimento a tais fatores seria essencial para o estabelecimento de uma relação de confiança - a relação médico/paciente ideal. Os clínicos entrevistados, de modo inte- 
ressante, têm uma visão do trabalho relativo à sua especialidade como sendo a única que propicia o tipo de consulta ideal: ouvindo o paciente, aconselhando-o, tocando-o, enfim, adotando posturas e procedimentos, mais do que decisões simplesmente técnicas e mecânicas.

O pensamento dominante sobre a atual situação da relação médico/paciente é de deterioração da mesma. "O médico não ouve mais o paciente, não toca mais no paciente, não tem tempo para o paciente, não mais é amigo do paciente" - são expressões freqüentes. Ora, um dos grandes "trunfos" do médico quanto à manutenção de sua autonomia técnica no trabalho seria justamente o raciocínio clínico elaborado a partir da anamnese e exame clínico, assessorado (ou não) por exames laboratoriais, chegando-se ao diagnóstico. Considerando-se que esses elementos compõem, grosso modo, o ato médico em si, temos que esse é o trabalho médico. Ou seja, deve fazer parte do trabalho médico, do seu atendimento ao paciente, realizar tais procedimentos. A partir do momento em que tais circunstâncias não se dão (e é essa justamente a queixa não só de nossos professores, mas da sociedade em geral) o médico perde a oportunidade de realizar um tipo de intervenção específica sobre o paciente, que só a ele competiria.

O médico "perde terreno" ao deixar de realizar rotinas e atividades tradicionalmente associadas ao seu trabalho, como anamnese, exame físico, papel de aconselhador... Há uma descaracterização da relação médico/paciente, nos moldes que se quer realizar. Em última instância, acaba sendo afetada a autonomia profissional do médico ${ }^{6}$. Este lamenta a desvalorização profissional e a deterioração da relação médico/paciente, considera-se responsável pela situação: "Nós fomos os culpados. Essa deterioração no relacionamento, o culpado foi o médico". Uma relação médico/paciente não adequada, portanto, constituiria importante fator de perda de confiança e credibilidade por parte do paciente, com conseqüências para o status da profissão médica, que tem na confiabilidade da clientela importante atributo.

Diante de tantos conflitos, é difícil que o discurso não assuma, freqüentemente, caráter de desabafo - aliás, a tônica de todos os depoimentos. Todavia, pelo fato de os docentes serem médicos também - e, como aqui pensamos e propomos, são deles os valores e pensamentos que prevalecem -, deve-se considerar que o sentimento de insatisfação, pessimismo e falta de perspectivas profissionais é da categoria médica como um todo (o que até atenuaria a gravidade da situação) ${ }^{7}$. Em todo caso, esses elementos estão lá, no pensamento e discurso dos docentes. Tal estado de espírito se agudiza quando surgem referências a um tempo, vivido por todos, em que 
a faculdade gozava de prestígio e melhores condições de exercício docenteassistencial.

Por outro lado, diante desse quadro, é curioso constatar que a maioria dos docentes se dedica à instituição de forma preponderante, ou seja, faz do hospital universitário seu principal local de trabalho. Tal constatação sugere que os docentes se sentem, de alguma forma, recompensados em seu trabalho. Traduzindo seu sentimento, um docente declara, orgulhoso: “(...) e tenho orgulho de te dizer isso! Esta universidade hoje tem muito de mim!".

\section{Referências Bibliográficas}

ALMEIDA, E. Medicina hospitalar. Medicina extra-hospitalar: duas medicinas? 1988. Dissertação (Mestrado em Saúde Coletiva) - Instituto de Medicina Social, Universidade do Estado do Rio de Janeiro.

ALMEIDA, M. J. Educação médica e saúde: possibilidades de mudança. Londrina: UEL, 1999.

BECKER, H. S. Boys in white: student culture. In: BECKER, H. S. et al. (Org.). A Medical School. Chicago: Chicago University Press, 1984.

CAMARGO JR., K. R. Medicina, médicos, doenças e terapêutica: exame crítico de alguns conceitos. Rio de Janeiro: IMS,UERJ, 1998 (Série Estudos em Saúde Coletiva, 170).

COELHO, E. C. Físicos, sectários e charlatães: a medicina em perspectiva histórico-comparada. In: MACHADO, M. H. et al. (Org.). Profissões de saúde: uma abordagem sociológica. Rio de Janeiro: Fiocruz, 1995.

DONNANGELO, M. C. F. Medicina e sociedade. São Paulo: Pioneira, 1975.

EDLER, F. C.; FERREIRA, L. O; SANTOS, M. R. Os impasses do ensino e da profissão médica no Rio de Janeiro no século XIX. Rio de Janeiro: Fiocruz, 1990.

FREIDSON, E. Profession of medicine: a study of the sociology of applied knowledge. Chicago: Chicago University Press, 1970.

FREIDSON, E. Professionalism reborn: theory, prophecy and policy. Chicago: Chicago University Press, 1994.

IMPAgliAZZO, S. P. A voz do Conselho Federal de Medicina: da defesa da ética à ação corporativa. 1999. Dissertação (Mestrado em Saúde 
Coletiva) - Instituto de Medicina Social, Universidade do Estado do Rio de Janeiro.

MACHADO, M. H. et al. (Org.). Profissões de saúde: uma abordagem sociológica. Rio de Janeiro: Fiocruz, 1995.

MERTON, R. K. Some preliminaries to a sociology of medical education. In: The student-physician introductory studies in the sociology of medical education. Massachussets: Harvard University Press, 1957.

REGO, S. T. A. A prática na formação médica: os estágios extracurriculares em questão. 1994. Dissertação (Mestrado em Saúde Coletiva) - Instituto de Medicina Social, Universidade do Estado do Rio de Janeiro.

REGO, S. T. A. O processo de socialização profissional na medicina. In: MACHADO, M. H. (Org.). Profissões de saúde: uma abordagem sociológica. Rio de Janeiro: Fiocruz, 1995.

SANTOS, P. M. Profissão médica no Brasil. MACHADO, M. H. (Org.). Profissões de saúde: uma abordagem sociológica. Rio de Janeiro: Fiocruz, 1995.

THOMPSON, P. A voz do passado: história oral. São Paulo: Paz e Terra, 1992.

\section{NOTAS}

1 Médica sanitarista, doutoranda em Saúde Coletiva (IMS/UERJ).

2 Médica, doutora em Saúde Coletiva, professora adjunta do Departamento de Planejamento e Administração em Saúde do IMS/UERJ.

3 Ver também os depoimentos que associam uma deterioração da relação médico/paciente com os médicos especialistas.

4 Impagliazzo (1999), em seu estudo sobre o pensamento de importante organização médica o Conselho Federal de Medicina (CFM) - também conclui que o ideal de serviço não é relevante para a categoria estudada, aparecendo o mesmo em seu discurso, mais com a intenção de se valorizar a corporação frente à opinião pública e respaldar reivindicações, do que representar o verdadeiro sentimento desse valor. A autora verificou, nesse contexto, que as declarações emitidas pelo órgão (publicadas em jornal próprio) referiam o atributo como um sentimento da categoria como um todo e não como específico do médico individualmente.

5 Ver depoimentos sobre a condição de assalariamento.

6 A deterioração da relação e a violação da ética são umas das maiores queixas do CFM ao trabalho médico atual. Aponta como causas a mercantilização da medicina, principalmente no tocante aos planos de saúde (Impagliazzo, 1999).

7 Ver, por exemplo, Pesquisa dos Médicos do Brasil (Machado et al., 1995); A voz do Conselho Federal de Medicina: da defesa da ética à ação corporativa (Impagliazzo, 1999). 


\section{ABSTRACT}

Medical School and its Reasons: on Professors and their Values. Physicians' Values and Impasses in Medical School

This study focuses on medical school professors and their professional values and behaviors, based on the hypothesis that the latter are present in the so-called hidden curriculum in medical education. The primary supposition is that such elements bear a close relationship to medical training, ultimately comprising a culture acquired in medical school over the course of the student's socialization process. This process is as important for professional identity (or belonging to the medical corporation) as the acquisition of skills and technical contents related to the actual exercise of the medical profession per se. The study thus analyzed the life histories of several professors from a public medical school in Rio de Janeiro, concentrating on the categories of autonomy, service ideal, clinical reasoning, and inter-peer relations as defined in the Sociology of Professions, in addition to recording specific reports on the careers of physicians who had become professors. We used oral histories obtained through eleven interviews with professors from different specialties. The article concludes that medical professors feel nostalgia for a past in which their profession bore unquestionable prestige, meanwhile expressing bewilderment at new situations, especially restrictions over their autonomy as liberal professionals. Lacking a policy proposal for either the teaching school or the medical corporation, they are less motivated than in the past, and this may constitute a negative factor in the socialization and formation of ethical values among their students.

Keywords: Medical profession; medical teaching; hidden curriculum; oral history.

Recebido em: 19/05/2003.

Aprovado em: 04/06/2003. 